\title{
STRATEGI DAKWAH SIASYAH \\ PARTAI PERSATUAN PEMBANGUNAN DI JAWABARAT
}

\author{
Ridwan Mubarok ${ }^{1 *}$ \\ 1 Fakultas Ilmu Dakwah dan Komunikasi UIN SGD Bandung \\ *Emali: ridwan_mubarak@uinsgd.ac.id
}

\begin{abstract}
For every Muslim, the role of civilization is identical to authentic mission as a leader as a leader in this earth, whose role is greater than leading a province or country. The participation of ulama, dai or da'wah movements in the political sphere is his right, but the missionary movement or organization must also be aware of and be aware of people or persons who want to manipulate da'wah as a vehicle for world politics. Da'wah movements or dai must be able to use various life instruments that exist today for the sake of da'wah. Ulama and the da'i who join in the organization movement or da'wah movement, must realize that they are part of the chain of struggle of the people. Now is the time for da'i or ulama to proclaim themselves from the past fetters that castrated the political life of the scholars.
\end{abstract}

Keywords: Da'wah, Siasyah, PPP.

\section{ABSTRAKSI}

Bagi setiap muslim, peran peradaban identik dengan misi otentik sebagai pemimpin sebagai pemimpin dimuka bumi ini, yang perannya lebih besar dibandingkan memimpin sebuah provinsi atau negara. Keikutsertaan para ulama, dai atau gerakan dakwah dalam ranah politik merupakan haknya, akan tetapi gerakan atau organisasi dakwah juga harus menyadari serta mewaspadai terhadap orang atau oknum yang hendak memperalat dakwah sebagai kendaraan politik dunia. Gerakan dakwah ataupun para dai harus dapat menggunakan berbagai instrument kehidupan yang ada saat ini untuk kepentingan dakwah. Ulama maupun para da'i yang bergabung dalam gerakan organisasi atau gerakan dakwah, harus menyadari bahwasanya dirinya merupakan bagian dari mata rantai perjuangan umat. Kini sudah saatnya para da'i ataupun ulama dapat memproklamirkan diri dari belenggu masa lalu yang mengebiri kehidupan politik para ulama, PPP menjadi salah satu alternatif.

Kata kunci: Dakwah, Siasyah, PPP 


\section{PENDAHULUAN}

Baik perspektif teoritis maupun perspektif praktis, perbincangan tentang makna siasah dalam semua sisinya tetap menjadi wacana aktual yang tak berkesudahan. Hal ini disebabkan, karena keberadaannya secara fungsional identik dengan keberadaan masyarakat itu sendiri. Selain itu, konsep siasah belumlah sepenuhnya menjadi kesepakatan semua orang. Bahkan masih banyak kalangan yang menganggap siasah sebagai sesuatu yang buruk dan harus dihindari. Siasah disinonimkan dengan tipu muslihat dan kelicikan. (Abu Ridha, Amal Siyasi; Gerakan Politik dalam Dakwah, (Bandung: Syaamil, 2004), hlm. 1).

Sebagai wacana dan upaya mendudukan istilah siasah, pengkajian terhadap istilah ini dalam perspektif Islam sangat diperlukan, terutama dalam kerangka penemuan konsep-konsep siasah alternatif untuk menyongsong millenium ketiga, setelah pemikiran siasah yang semata-mata disandarkan kepada akal manusia seperti Liberalisme, Sosialisme, dan Komunisme yang nyata menglamai kegagalan yang bertubi-tubi. Di sisi lain, pemikiran siasah Islam masih menjadi bahan polemik, termasuk dikalangan cendikiawan muslim sendiri. Akibatnya, wujud konsep siasah Islam belum terjawab tuntas. Bahkan pertanyaan-pertanyaan, apakah Islam mengenal sistem siasah atau tidak, apakah Islam memiliki konsep siasah seperti dikenal dalam kajian-kajian ilmiah yang menekankan pada pendekatan empiris atau tidak.

Memang perjalanan sejarah kontemporer kaum muslimin pernah melalui satu fase dimana sebagaian dari mereka memandang siasah sebagai sesuatu yang tidak penting, bahkan kotor dan menjijikan. Seolah-olah siasah menjadi pohon larangan dan pohon kutukan yang tidak boleh didekati apalagi dicicipi buahnya. Siapa saja yang mencoba mendekatinya akan terkena kutukan dan bisa jadi membawa dampak buruk yang sangat luas terhadap kehidupan umat. Dampak buruk yang diakibatkannya bukan saja menimpa yang bersangkutan tetapi juga dapat menimpa orang-orang yang sama sekali tidak terlibat dalam urusan siasah. Akibatnya, para politisi dianggap sebagai orang yang terkena Lepra yang harus dikucilkan dari kehidupan umum. Mereka berlindung kepada Allah agar dari ketularan penyakit rajulun siyasi (politisi): "Aku berlindung dari siasah dan rajulun siyasi." .

Mereka menganggap siasah sebagai sesuatu yang harus dienyahkan dari kerangka dan wacana berpikir atau aktivitas seorang muslim, lebih-lebih aktivitas dakwah. Munculnya persepsi tentang siasah dan rajulun siyasi seperti itu disebabkan oleh satu kenyataan bahwa banyak orang yang bergelut dalam dunia siasah sering menampilkan prilaku siasah model penjajah, kaum sekuler yang kotor, penuh intrik dan pengkhianatan. Apalagi setelah falsafah Machiavelli mendominasi jagatsiasah dan mengaduk-aduk cara berfikir manusia. Muhammad Abduh, seorang pembaharu pemikiran kaum muslimin terkemuka, dalam kontek 
melihat kenyataan buruk seperti itu, sampai-sampai mengatakan, "Aku berlindung kepada Allah dari orang yang sudah, sedang, dan akan bersiasah, serta dari menjadi rajulun siyasi (politisi)." Dikutip oleh Yusuf Al Qardhawi, Fatwa Mu'ashirah dalam sub judul Islam wa Siasah.

Namun, dengan semakin meluasnya kebangkitan Islam dan terkuaknya kenyataan bahwa penjajahan siasah yang selama ini berlangsung telah menghancurkan seluruh milik umat, muncul kesadaran baru dikalangan kaum muslimin bahwa siasah merupakan bagian dari kehidupan. Ia adalah salah satu dimensi dari dimensi-dimensi kehidupan manusia. Posisinya sama penting dengan segemen-segmen kehidupan lainnya seperti: ekonomi, sosial, pendidikan, dan budaya. Bahkan, akhir-akhir ini dikalangan kaum muslimin tumbuh kesadaran yang semakin meningkat bahwa siasah adalah sesuatu yang melekat pada lingkungan hidup manusia yang tak mungkin diabaikan. Peningkatan kesadaran itu, sejalan dengan kepesatan perkembangan dan kompleksitas kehidupan manusia.

Asumsi tersebut setidaknya dapat ditelusuri dengan indikasi semakin meluasnya perbincangan masalah siasah, terutama siasah Islamiyah, baik untuk kepentingan akademis ataupun untuk kepentingan praktis, baik sekedar wacana maupun bersifat ideologis. Demikian pula kita menyaksikan betapa antusiasnya aspirasi masyarakat, termasuk masyarakat muslim, terhadap dunia siasah dengan segala problematikanya. Sebagaimana kita ketahui bersama, alam reformasi saat ini, telah mampu melahirkan banyak partai politik baik yang berlabel agama maupun non agama. Ada partai politik yang menggunakan label agama, seperti Partai Islam dan Partai Kristen, sedangkan partai politik non agama, diantaranya berlabel sosialis, nasionalisme, dan berbagai variannya. (A M Fatwa, Satu Islam Multipartai; Membangun Integritas di Tengah Pluralitas.(Bandung: Mizan, 2002), hlm.93)

Keberadaan parpol dalam suatu negara, dianggapa sebagai salah satu perangkat institusi demokrasi karena fungsi parpol diantaranya, pertama menyerap dan mengartikulasikan aspirasi atau kepentingan rakyat; kedua sarana sosialisasi dan komunikasi politik, dan ketiga sebagai media penyaluran perbedaan pendapat yang terjadi di masyarakat maka keberadaan partai politik yang kuat menjadi faktor penting dalam kehidupan berbangsa. Sebenarnya, keberadaan parpol memang tidak bisa dilepaskan dari kepentingan kekuasaan. Sirkulasi kekuasaan harus diatur melalui mekanisme yang harus ditaati oleh semua warga negara. Oleh karena itu, sebagai media penyaluran perbedaan pendapat melalui cara parlementarian, sesungguhnya keberadaan parpol akan memindahkan konflik di dalam masyarakat ke lembaga-lembaga perwakilan. Pengelolaan perbedaan pendapat tersebut tentu sangat bergantung pada pola dan tradisi yang dikembangkan oleh lembaga perwakilan, apakah menghargai perbedaan sebagai 
R. Mubarok

sebuah rahmat atau tidak.

Adanya parpol yang kuat dan mandiri akan mampu mengontrol jalannya pemerintahan. Sejarah membuktikan, lembaga eksekutif selalu dominan dan tidak terkontrol akibat disfungsionalisasi partai-partai politik yang tidak mampu mengawasi dan mengontrol jalannya pemerintahan. Sekarang sudah berkembang banyak parpol. Partai politik yang yang berbasiskan masa kaum muslimin lebih dari satu, diantaranya PPP, PKB, PBB, PNU, PKS dan lain sebagainya. Belum termasuk partai politik non agama lainnya, dari sinilah muncul persoalan, diantaranya: 1 . apa visi dan misi masing-masing partai, 2. bagaimana masa depan Indonesia dengan banyak hadirnya partai Islam?. Perubahan asas dan lambang PPP serta tumbuhnya partai-partai Islam baru merupakan satu rangkaian yang cukup panjang atas perjalanan sejarah "Islam Politik" di Indonesia.

\section{HASIL DAN PEMBAHASAN}

Istilah "Islam Politik" sebenaranya tidak terlampau tepat jika dikaitkan dengan Islam sebagai sistem hidup yang komprehensif dan universal. Karenanya, Islam politik yang dimaksud ialah peristiwa-peristiwa politik yang dilakukan oleh komunitas Islam dengan segenap perilaku dan capaian-capaian politik yang telah dihasilkan. Bila dirunut dalam konteks partai politik modern - meminjam istilah sejarahwan Taufik Abdullah - "halaman pertama" Islam politik di Indonesia diawali oleh eksisnya SI (1912). Walaupun apa sebenarnya definisi partai politik Islam itu masih debatable, setidaknya ada dua ciri untuk mengidentifikasi sebuah partai politik sehingga disebut partai politik Islam. Pertama, ada unsur substansialias idealisme yang di eksplorasi dari ajaran-ajaran Islam sebagai meminjam istilah Nurcholish Madjid - "nilai-nilai dasar" (basic values) yang mesti dipegang teguh. Wacana-wacana substanstif inilah yang disebut ideologi yang bersifat doktrinal.

Dalam konteks ini, Islam dijadikan bahan rujukan utama untuk memutuskan kebijaksanaan politik. Oleh karenanya, diharapkan setiap keputasan politik yang diambil harus mencerminkan dan merefleksikan normatifitas ajaran Islam. Dengan kata lain, unsur idealismemerupakan identifikasi normatif politik Islam. Kedua, eksplorasi simbol-simbol keislaman, simbol bulan bintang misalnya, begitu populer sebagai simbol umat Islam. Tidak mengherankan jika banyak partai Islam yang mengekplorasi simbol tersebut. Demikian pula dengan simbol Ka'bah ataupun yang lain, yang dianggap mewakili umat Islam. Musa Kazhim dan Alfian Hamzah, 5 Partai dalam Timbangan; Analisis dan Prosfek, (Bandung: Pustaka Hidayah, 1999), hlm. 305.

Masing-masing partai tentunya mempunyai asas partai yang dalam bahasa politik berfungsi sebagai landasan, haluan, dan flatform partai dalam meniti kehidupan partainya. Nilai asas merupakan ruh partai itu yang menjadi sumber inspirasi dan motivasi yang menggerakan kehidupan partai. Asas ini yang akan 
menentukan identitas perjuangan partai politik yang bersangkutan.

Pandangan politik partai terhadap dunia sering disebut sebagai ideologi politik partai. Memang kita akui bahwa istilah ideologi digunakan oleh sejumlah penulis dalam arti yang berbeda. Ada yang menekankan pada unsur ideos-nya, yang berarti gagasan, atau lebih tepatnya nilai-nilai; ada yang menekankan pada unsur logos-nya, yang berarti sistem yang berlaku dalam suatu negara. Secara ringkas, ideologi mengandung pengertian gagasan, keyakinan, nilai, dan pandangan hidup dalam negara atau politik. Jadi pemikiran atau pandangan politik tertentu sudah inhern dengan kehidupan partai. Meskipun suatu partai memiliki program yang bersifat universal, misalnya sama-sama memperjuangkan keadilan, demokrasi, dan masyarakat madani, partai politik tetap tidak bisa terlepas dari pandangan tertentu yang menjadi nilai dasar dalam menentukan ciri dan identitas partainya. Dengan kata lain, ideologi partai politik itu tercermin dari visi dan misi politik suatu partai. Visi dan misi partai bisa kita lihat dari programprogram partai yang diperjuangkan.

Persepsi umum terhadap partai politik dan politisi terkadang tidak menyenangkan. Wilayah politik dan para politisi dianggap sebagai sumber keonaran. Politik sudah dianggap sebagai dunia hitam, dan dalam ukuran normatif kita harus menghindarinya. Anggapan tersebut tidak salah selama para politisi dalam pola, sikap, dan perilakunya tidak menggunakan sandaran etismoral (agama); untuk mendapatkan keinginannya mereka menghalalkan segala cara; dan dalam pergulatan kekuasaan yang dijalani menimbulkan budaya kekerasan politik. Dalam wilayah politik dan hidup di partai politik, nilai inipun seharusnya ditegakkan oleh para politisi kita. Kita harus mampu menempatkan wilayah politik sebagai sarana perjuangan untuk menegakan nilai-nilai. Karena kita muslim, nilai yang kita tegakkan adalah berdasarkan Al-Qur'an dan Sunnah Rasul. Dengan kata lain kita melakukan ibadah di bidang politik untuk mendapatkan ridha dari Allah Swt.

Perjuangan nilai itu harus ditopang dengan kekuasaan politik. Suatu perjuangan nilai bila tidak mempunyai posisi atau kekuasaan tidak akan efektif dan membesar. Jika umat Islam tidak mempunyai kekuasaan politik, bisa dipastikan akan berada di kelompok pinggiran dalam proses politik. Bila demikian halnya, umat Islam tidak akan bisa lagi memandu jalannya perubahan bangsa.

Jadi, seorang politisi yang aktif di parpol harus memiliki pemikiran komprehensif bahwa mereka masuk wilayah politik untuk memperjuangkan nilainilai, dan dalam mengimplementasikan nilai-nilai tersebut harus mempunyai posisi. Posisi adalah bagian dari kekuatan untuk mengimplementasikan nilai-nilai. Seorang politisi, dalam mewarnai panggung politik nasional, idealnya memang seorang moralis. Bukan mengejar kekuasaan untuk kepuasaan diri, melainkan kekuasaan untuk mengabdi kepada agama, bangsa dan negara. 
Berkembangnya partai Islam memang tidak terpisah dari aspek historis, sosiologis, dan politik bangsa Indonesia. Awal berkembangnya organisasi Islam modern, bisa kita lihat pada Sarikat Dagang Islam (SDI), yang bergerak pada bidang ekonomi dan perdagangan, terutama batik. SDI yang semula organisasi perekonomian dan pedagangan antar anggota kemudian berubah menjadi organisasi politik, SI. SI ini kemudian pecah menjadi dua, SI putih dan SI merah (kemudian menjadi PKI dengan tokohnya Semaun, Alimin, dan Dharsono). A M Fatwa, Satu, (hlm. 96).

Kemudian menyusul berdirinya Muhammadiyah, Persis, Nahdlatul Ulama (NU), dan seterusnya yang mewarnai peta umat Islam hingga sekarang. Oleh karena itu, dari sejarah terlihat bahwa berdirinya lembaga sosial keagamaan di Indonesia merupakan fenomena khas umat Islam di Indonesia. Kenyataan sosiologisnya, masing-masing lembaga sosial keagamaan tersebut, diantaranya Muhammadiyah, Persis, NU, DDII, Mathlaul Anwa, dan Al-Waslhiyah, telah mempunyai segmen kulturalnya masing-masing. Segmentasi kultural ini pada akhirnya membentuk ciri masing-masing lembaga sosial keagmaan tersebut.

Melihat hal seperti ini, keberadaan banyak partai Islam akan menimbulkan beberapa nilai tambah dan kekurangan. Positifnya adalah, pertama, rakyat akan semakin terbuka menyalurkan aspirasi politiknya, tanpa intimidasi. Udara kebebasan ini lambat laun akan menjadikan rakyat kita semakin rasional, kritis, dan partisipatif dalam mengikuti segala proses politik yang sedang terjadi. Pendidikan politik masyarakat akan berjalan karena masyarakat sudah semakin tahu tentang siapa dirinya, posisinya, tujuannya, dan pemerintahan yang menjadi idamannya.

Kedua, proses sosial politik akan lebih terbuka dan transparan sehingga budaya penggarapan dan intervensi penguasa kepada segala bentuk mekanisme sosial yang berkembang di masyarakat saat itu menjadi nilai tabu. Kehidupan demokrasi di Indonesia akan terbangun dalam suasana keterbukaan, transparan, dan adil. Apabila berjalan, fungsi-fungsi kontrol dari rakyat dan atau melalui lembaga perwakilannya akan mampu membatasi kekuasaan pemerintah.

Ketiga, umat Islam akan diuntungkan karena ada parpol yang concern memperjuangkan aspirasinya. Yang terjadi kemudian adalah adanya mekanisme pemberdayaan visi politik masyarakat. adapun aspek negatifnya adalah, pertama, bila arus keterbukaan ini berkembang menjadi anarki, sehingga malah menghancurkan jalannya reformasi dan nilai toleransi antar dan antara umat beragama. Yang terjadi kemudian adalah sikap saling curiga dan akan membahayakan biduk Indonesia yang terancam karena faktor SARA.

Kedua, keberagaman pandangan politik Islam antar partai Islam, akan menyebabkan beragamnya pola dan perilaku politik masing-masing partai Islam. Yang dikhawatirkan Dr. Kuntowijoyo - seorang intelektual Muslim yang tidak sepakat dengan berdirinya partai Islam di Indonesia - adalah bahwa tumbuhnya 
partai Islam akan menyebabkan reformasi yang berarti kebebasan, demokrasi, dan transparansi, berubah menjadi ketertutupan, mempribadi, otoritarian, dan eksklusivisme. Akan tetapi, hal itu dibantah oleh Yusril Ihza Mahendra bahwa partai Islam tidak akan menyebabkan ekskulivisme sebab yang akan dibangun adalah suatu sistem perpolitikan baru yang didasarkan pada nilai-nilai Islam yang universal. Sehingga antar partai Islam sendiri sangat mungkin terjadi konflik. Meskipun konflik sudah melekat dengan kehidupan parpol, paling tidak dalam memperjuangkan nilai-nilai demokrasi tersebut harus berdasarkan nurani umat. Bukan berdasarkan kepentingan pribadi. Dalam hal ini, menurut penulis, keberagaman pandangan politik ini pada dasarnya adalah sebuah keberagaman dalam interpretasi dalam hubungannya antara Islam dan negara atau politik.

Ketiga, kecurigaan ideologis akan diembuskan oleh siapapun yang termasuk kelompok anti Islam dan Islam phobia dalam usaha membuat citra yang buruk terhadap partai islam, misalnya dengan isu Negara Islam Indonesia (NII) dan Islam anti demokrasi. Memang ini terdengar menyakitkan, tetapi menurut penulis, justeru ini adalah suatu tantangan bagi partai Islam untuk membuktikan dirinya bahwa apa yang dituduhkan itu sama sekali tudak benar. Misalnya, dengan mengembangkan suasana dialogis antar parpol, menjadi lokomotif bagi terbentuknya masyarakat madani, Masyarakat madani sering diidentikkan dengan civil society, yakni suatu masyarakat yang mempunyai ciri: (1) mempunyai kemandirian dan ketangguhan ketika berhadapan dengan negara; (2) mampu membatasi intervensi kekuasaan negara; (3) adanya ruang publik bebas dalam mengapresiasikan segala pendapat secara lisan maupun tulisan kepada masyarakat dan pemerintah.

partai yang menghargai perbedaan pendapat dan pluralisme, partai yang tetap mempunyai komitmen keislamandan kebangsaan yang satu, tidak terpisah, dan menjadi partai harapan rakyat Indonesia. Akhirnya masa depan ada ditangan kita sebagai warga bangsa Indonesia. Apakah kita sanggup keluar dari kemelut sejarah dan mencegah agar tragedi politik tidak terulang lagi. Dibutuhkan perenungan dan kejernihan berpikir, kebijaksanaan, dan bersandar pada tali silaturahmi yang tulus. Tentunya dibutuhkan sikap sebagai seorang Muslim yang negarawan dan bertanggung jawab terhadap masa depan bangsanya sendiri.

Sebagaimana kita ketahui, bahwasanya Nahdatul Ulama (NU) merupakan sebuah organisasi dakwah yang berorientasi pada terwujudnya cita-cita Islam yang berpegang pada ablus sunnab wal jamaah. Kita-pun patut menyadari bahwasanya pembangunan bangsa ini dan bahkan benua ini pun tidak akan terlepas dari peran serta ulama dalam kancah politik. Apabila kita melihat sejarah Nabi, maka kita akan juga melihat aktivitas dakwah Nabi dalam perpolitikan, yang tentunya politik yang digunakan untuk kepentingan dakwah, bukan politik semata. Sebagai manusia yang menyatakan dirinya da'i atau ulama harus dapat menempatkan diri sebagai da'i yang menjadikan dakwah sebagai tujuan utama 
dalam berpolitik. Ada beberapa babak hubungan antara NU dan politik praktis yang dapat kita urai, pertama, pada masa kolonial Belanda. Dasawarsa-dasawarsa awal kelahiran NU lebih banyak dilewati dengan konsolidasi diri. Tanpa konsolidasi internal, sebuah organisasi laksana rumput kering yang mudah tersulut api. Karenanya pada dasawarsa awal ini, NU tidak banyak terlibat dalam peristiwa politik. Kedua, pada masa pendudukan Jepang. Pada masa ini-pun NU tidak banyak terbabit dalam perkara politik. Karena, sebagai organisasi kemasyarakatan yang besar, partisipasi NU salah-salah bisa memakan korban dan biaya perjuangan yang besar. Namun begitu, ulama dan pimpinan NU atas praktik saikeirei (keharusan membungkukkan badan kearah kaisar) yang sangat menyerupai rukuk dalam shalat. Pada 1942, Kiai Hasyim Asy'ari sampai dipenjara beberapa bulan karena penolakannya terhadap praktik saikeirei ini. Ketiga, pada masa menuju kemerdekaan. Tidak seperti sebelumnya, kini NU bergiat betul, bahkan radikal, dalam menyikapi perjuangan menyongsong kemerdekaan. Sikap yang agak sulit dibayangkan terjadi pada NU yang terkenal lembut dan kompromistis. Kiai-kiai NU, secara individual, menyingsingkan lengan baju dan melibatkan diri secara langsung dalam mengorganisasi dan memobilisasi "pasukan" pejuang kemerdekaan.

Disadari ataupun tidak, sudah sekian lama gerakan-gerakan dakwah Islam dijauhkan dari wilayah politik, Politik; Fikrah dan Thariqah. Fikrah (konsep) yang mendasari politik suatu negara adalah pemikiran yang menjadi asas hubungan negara itu dengan berbagai bangsa dan negara lain. Negara-negara yang tidak memiliki suatu ideologi yang dianut, fikrah-nya beragam dan bermacam-macam yang berpotensi untuk berubah. Negara-negara semacam ini lebih cocok dibahas dari segi khithah dann uslub politik. Tidak cocok dibahas dari segi fikrah politik. Adapun negara-negara yang menganut suatu ideologi, fikrahnya akan tetap dan tidakmberubah-ubah, yakni penyebarluasan ideologi yang dianutnya ke seluruh dunia dengan suatu thariqah (metode) yang tetap, meskipun uslubnya berbedabeda dan berubah-ubah. Negara semacam ini cocok dibahas dari segi fikrah politik.Taqiyuddin An-Nabhani, Konsepsi Politik. Hizbut Tabrir, (Jakarta: Hizbut Tahrir, 2005:11).

terlebih lagi pada pemerintahan orde baru. Pada masa itu, dakwah dan politik merupakan wilayah yang berbeda, dimana dakwah menyeru pada perbuatan moral transendent, sedangkan politik adalah wilayah kotor yang horizontal berliku bagaikan hutan belantara. Tentu saja hal ini membuat terpinggirkannya para ulama salaf dalam kancah perpolitikan nasional. Ulama hanya mengurusi wilayah mesjid dan diperlukan ketika pembacaan do'a saja, sedangkan para politisi merupakan komunitas yang mengurusi permasalahan masyarakat dan negara yang carut marut. Segala gerakan dakwah yang hendak tumbuh dengan kesadaran untuk membangun bangsa dicurigai dengan sinis, dicap pemberontak bahkan teroris. Stigma ini melekat dan mulai mendarah

Anida: Aktualisasi Nuansa Ilmu Dakwah 17(2) (2017) 19-36 
daging sehingga apapun gerakan dakwah yang dimotori para ulama tidak diberikan tempat dalam perpolitikan nasional. Berbeda jauh dengan apa yang dilakukan oleh Rasulullah SAW, dimana Nabi Muhammad SAW merupakan penyeru (Da'i) pada kebenaran sekaligus kepala pemerintahan di zamannya.

Aksiologi dakwah, al-Qur'an menegaskan suatu misi dan tujuan sebagai pesan moral utamanya. Adalah khilafah dan risalah. Hal itu diwujudkan dalam wujud penghayatan (internalisasi), penyebaran (transmisi) dan perubahan atau pembangunan (transformasi) nilai-nilai kebaikan (al-birr) dan kebenaran serta kesucian sebagai hidayah ilahi yang perlu ditegakkan dalam kehidupan sosial budaya dari masa ke masa, sesuai dengan makna serta tugas nabi dan rasul sebagai pembawa kabar gembira, dan penyampai pesan risalah ilahi. Tujuan dakwah Qur'ani dapat dikategorikan ke dalam empat bentuk: pertama, tujuan ideal, ialah terciptanya situasi dan kondisidar al-salam atau al-nur, kedua, tujuan institusional adalah tegaknya kekhilafahan; ketiga, tujuan konstitusional, yaitu tegaknya tata aturan ibadah dan muamallah sesuai dengan ajaran Islam; keempat, tujuan operasional adalah tegaknya al-birr dan al-haqq yang direfleksikan dalam wujud akhlak mulia (makarim al-akhlaq). Asep Muhyidin, Imu Dakwah; Dakwah dalam Al-Qur'an, (Bandung: Pustaka Bani Quraisy, 2004:13).

Ulama atau da'i sudah saatnya kini memasuki seluruh wilayah kehidupan berbangsa dan bernegara. Baik ekonomi, sosial, budaya, akademik, maupun politik. Karena pada hakikatnya Islam itu universal dan komprehensif. Politik yang digunakan para ulama ataupun da'i tentunya bukanlah politik yang menghalalkan segala cara, dan menjadikan kekuasaan sebagai tujuan semata. Perilaku seperti ini tentunya akan mengakibatkan kekacuan politik, bahkan dakwah itu sendiri. Dalam berpolitik, sudah semestinya kita dapat menggunakan dakwah sebagai tujuan utama. Politik hanyalah salah satu media dalam berdakwah, hingga para da'i ataupun aktivis dakwah yang memasuki ranah politik harus dapat menjadi wakil rakyat sekaligus da’i yang menyampaikan kebenaran untuk dijadikan acuan bagi anak bangsa.

Gerakan dakwah ataupun para da'i yang memasuki ranah politik hendaknya harus tetap berorientasi pada pembangunan masyarakat muslim, bukan beroreintasi pada golongan atau kelompok tertentu. Gerakan dakwah sepanjang sejarahnya tidak boleh melalaikan setiap aspirasi dari masyarakat, bahkan harus selalu aspiratif terhadap cara pembangunan masyarakat muslim, sebagaimana yang dicontohkan Nabi Muhammad SAW.

Para da'i atau gerakan dakwah saat ini memiliki peran dan tanggung jawab dalam membangun peradaban, yakni peradaban yang menyeimbangkan bumi dan langit, peradaban yang bersumberkan dari intisari kehidupan hakiki yaitu Islam itu sendiri. Segala sesuatu yang berasal dari langit merupakan pekerjaan para da'i untuk dapat mentransformasikan serta membumikannya pada seluruh masyarakat. Al-Mawardi memberikan syarat untuk tercapainya cita-cita 
sosial dan politik peradaban manusia.

Pertama, berkaitan dengan pengaturan masalah publik. Menegenai pengaturan masalah publik, tentunya bukanlah pengaturan secara an sich semata, namun pengaturan publik yang berlandaskan pada tatanan nilai yang baik dan tidak menyesatkan. Sayarat kedua yang berkaitan dengan mewujudkan keshalihan setiap warga, yang menyangkut masalah nilai-nilai yang dapat membentuk individu-individu yang shalih. Akan tetapi keshalihan pribadi yang dimiliki para dai maupun gerakan dakwah harus dapat diimplementasikan menjadi keshalihan kolektif bagi masyarakat dunia. Pada umumnya, mewujudkan manusia yang memiliki kepribadian yang shalih dimaksudkan agar manusia-manusia tersebut dapat meningkatkan kualitas hidup serta berperanserta dalam membangun gerakan peradaban (amal adhari). Sedangkan politik merupakan salahsatu bagian dari peradaban itu sendiri.

Bagi setiap muslim, peran peradaban identik dengan misi otentik sebagai pemimpin sebagai pemimpin dimuka bumi ini, yang perannya lebih besar dibandingkan memimpin sebuah provinsi atau negara. Keikutsertaan para ulama, dai atau gerakan dakwah dalam ranah politik merupakan haknya, akan tetapi gerakan atau organisasi dakwah juga harus menyadari serta mewaspadai terhadap orang atau oknum yang hendak memperalat dakwah sebagai kendaraan politik dunia. Gerakan dakwah ataupun para dai harus dapat menggunakan berbagai instrument kehidupan yang ada saat ini untuk kepentingan dakwah. Ulama maupun para da'i yang bergabung dalam gerakan organisasi atau gerakan dakwah, harus menyadari bahwasanya dirinya merupakan bagian dari mata rantai perjuangan umat. Kini sudah saatnya para da'i ataupun ulama dapat memproklamirkan diri dari belenggu masa lalu yang mengebiri kehidupan politik para ulama.

Sebagai seorang anak manusia, sudah seyogianya menanamkan prinsip sebagai seorang da'i dengan memproklamirkan Nabnu Du'at qobla qulli sai'in, kami adalah da'i sebelum menjadi apapun. Apabila tertanam dalam diri kita pernyataan tersebut maka, peran yang kita miliki, pada hakikatnya kita semua dalah da’i yang senantiasa menyamapaikan amar ma'ruf dan nahi munkar. Dalam menyampaikan kebaikan dan mencegah kemunkaran tidaklah hanya berada di mimbar-mimbar mesjid, namun harus dilakukan diseluruh penjuru tempat, baik di kelas, kampus, pasar, bahkan di parlemen sekalipun. Karena menyampaikan kebaikan adalah hak sekaligus kewajiban bagi kita semua. Ladang dakwah bukanlah milik sekelompok golongan atau gerakan dakwah tertentu, namun ladang dakwah adalah milik gerakan dakwah manapun, tentunya dengan bingkai amar ma'ruf nahi mungkar. Karenanya, mengingat urgensi peran dakwah yang sangat strategis dalam rangka membangun umat yang baldhatun thoyyibatun warabbun ghafur.

Metode penelitian ini menggunakan dua metode, yaitu: pertama, metode deskriptif-analisis dengan penekanan pada analisis yang menggabungkan unsur

Anida: Aktualisasi Nuansa Ilmu Dakwah 17(2) (2017) 19-36 
dakwah (bahasa) dan siasah. Yang dimaksud dengan metode deskriptif analisis adalah gagasan atau ide yang terkandung dalam bentuk media dakwah yang dalam penelitian ini dimaksudkan dengan metode dakwah siasah yang dilakukan oleh ulama Partai Persatuan Pembangunan (PPP) Kabupaten Cianjur. Winarno Surakhmad menyebutkan bahwa penyelidikan dengan memakai metode deskriptif bertujuan untuk memecahkan permasalahan pada masa sekarang, di antaranya adanya penyelidikan dengan penuturan, analisis dan klasifikasi. Winarno Surakhmand, Penelitian Ilmiah: Dasar, Metode dan Teknik, (Bandung: Tarsito, 1999), hlm. 134. Metode pengumpulan data juga bisa dilakukan dengan menuliskan, mengedit, mengklasifikasi, mereduksi, dan menyajikan. Nung Muhadjir, Metodologi Penelitian Kualitatif, (Yogyakarta: Rake Sarasin, 1996), hlm. 30.

Kedua, Content Analisis (analisis isi) yang merupakan analisis ilmiah tentang isi pesan suatu komunikasi. Analisis isi dapat digunakan untuk memperoleh keterangan dari isi komunikasi yang disampaikan dalam bentuk lambang. Analisis isi dapat digunakan untuk menganalisis semua bentuk komunikasi, diantaranya: surat kabar, buku, puisi, lagu, cerita rakyat, lukisan, pidato, surat peraturan, musik, teater dan lain sebagainya. Andi Bulaeng, Metode Penelitian Komunikasi Kontemporer, (Yogyakarta: Andi Offset, 2004), hlm. 171.

Dengan demikian penelitian ini berusaha untuk menangkap pesan moral (dakwah) yang terkandung dalam karya materi dakwah siasah dalam konteks dakwah bil-qalam, bil lisan, maupun dakwah bil hal, sehingga isu-isu yang diangkat ada relevansinya dengan persoalan-persoalan yang sedang berkembang. Jenis data dalam penelitian ini merupakan data kualitatif dari masalah yang terangkum dalam rumusan masalah yaitu data tentang konsep teoritis dan praksis dari pesan dakwah Islam yang termuat dalam materi dakwah siasah PPP Kab. Cianjur. Jika dilihat dari fokus penelitiannya, penelitian ini menitik beratkan pada kajian konseptual berupa butir-butir pemikiran para fungsionaris partai, maka jenis data penelitian ini, merupakan jenis data kualitatif.

Sumber data yang digunakan dalam penelitian ini adalah sumber data primer dan sumber data sekunder. Sumber data primer yaitu data yang ada hubungannya dengan topik bahasan. Data primer diperoleh dari responden yang diteliti, yakni segenap informasi yang bersumber dari simpatisan dan fungsionaris DPC. PPP Kab. Cianjur. Adapun hal utama yang dibahas dalam penelitian ini, yakni materi-materi siasah yang mengandung pesan dakwah.

Sedangkan sumber data sekunder, yaitu data yang diambil dari berbagai karya dan pemikiran pakar dakwah siasah lainnya yang sedikit banyak berkaitan dengan penelitian ini, ditambah dengan data lain yang berasal dari komentar para penulis lain yang diterbitkan di berbagai media massa, jurnal, buku-buku, makalah-makalah, situs dan skripsi yang mengkaji konsep dan proses dakwah melalui Siasah di DPC. PPP Kabupaten Cianjur. 
Penulis menggunakan analisis secara deduktf dan induktif. Matode deduktif digunakan dalam rangka memperoleh gambaran umum tentang strategi dakwah melalui siasah PPP sebagaimana yang terlihat dalam kiprahnya di tengah masyarakat. Sedangkan metode induktif, dipakai dalam rangka memperoleh gambaran tentang proses dialektis antara realitas yang dihadapi fungsionaris DPC. PPP dengan konsep strategi dakwah siasah terutama yang mengandung pesan-pesan dakwah.

\section{Strategi Dakwah PPP}

Merujuk pada makna yang terkandung dalam al-Qur'an surat al-Nahl (16:125), dakwah Islam dapat dirumuskan sebagai kewajiban muslim mukallaf untuk mengajak, menyeru dan memanggil orang berakal menjalani jalan Tuhan dengan cara hikmah, mauzhah hasanah (supermotivasi positif), dan mujadalah ahsan (cara-cara yang lebih metodologis), dengan respon positiif atau negatif dari orang berakal yang diajak, diseru dan dipanggil disepanjang zaman dan di setiap ruang.

Hakikat dakwah Islam tersebut adalah perilaku keislaman muslim yang melibatkan unsur da'i, maudhu atau pesan, wasilah atau media, uslub atau metode, mad'u dan respon serta dimensi hal-maqom atau situasi dan kondisi. Interaksi antar unsur dakwah Islam ini dalam semua tataran praksisnya adalah obyek formal dan obyek material (perilaku keislaman muslim) menjadi substansi ilmu dakwah Islam. Dari sisi obyek materialnya, dakwah Islam bersenutuhan dengan kajian ilmu keislaman selain dakwah dan tentang perilaku. Dengan demikian ilmu dakwah berkarakter interdisipliner.

Hakikat dakwah Islam ini menunjukkan bahwa terdapat tiga bentuk utama dalam proses mendakwahkan Islam, yaitu, pertama, melalui ahsan qawl atau bahasa yang baik, kedua, melalui ahsan amal atau perbuatan baik atau reformatif, dan ketiga, keterpaduan bentuk keduanya yakni gerak percontohan yang baik. Mengacu pada uraian yang telah dikemukakan di atas, maka lahirlah dua proposisi hakikat dakwah Islam. Pertama, dakwah Islam adalah proses internalisasi, transmisi, difusi, institusionalisasi dan transformasi Islam dalam totalitas kehidupan manusia mukallaf guna mencapai hakikat tujuan hidup du dunia kini dan akhirat kelak. Kedua, bahwa proses dakwah Islam dari segi konteksnya mengharuskan terjadinya ketumpangtindihan dalam fokus dan pemokusannya.

Dalam pembicaraan sehari-hari, terutama dikalangan awam, antara pengertian politik dan siasah nyaris tidak berbeda. Politik sering disebut siasah, demikian pula sebaliknya. Padahal, kalau kita mengacu kepada hakikat sebuah makna seperti dikemukakan di atas bisa jadi tidak sesederhana itu. Kita akan menemukan sejumlah perbedaan, setidak-tidaknya penekanan substansi, mengingat pemberian makna referensi satu kata tidak dapat dilepaskan dari 
pemahaman pemberi makna itu sendiri terhadap ciri referensi yang diacu. Artinya, konseptualisasi suatu istilah, termasuk istilah politik dan siasah, sangat ditentukan oleh akar budayanya, oleh masyarakat yang memberikan artinya terhadapnya. Oleh sebab itu, jika kedua istilah itu ditelusuri akar budayanya masing-masing, bisa jadi akan memunculkan perbedaan yang cukup signifikan, sekali lagi setidak-tidaknya dalam penekanan.

Dari perbedaan-perbedaan yang mungkin muncul dari kedua istilah yang substansinya tidak jauh berbeda tersebut diharapkan dapat memberikan inspirasi untuk memilih istilah yang lebih tepat bagi pengertian politik yang dinisbatkan kepada Islam. Apakah politik Islam atau siasah Islam? Sebab penggunaan istilah yang tepat bagi politik Islam setidaknya dapat membantu keika kita mencoba memahami hubungan Islam dengan jagat siasah yang memiliki kandungan makna yang sangat luas dan kompleks. Dalam banyak hal ketepatan penggunaan istilah sangat membantu pemahaman kita terhadap satu istilah.

Dalam dunia filsafat dikemukakan pula beberapa pemikiran tentang politik. Pemikiran aprioristik Aristoteles tentang politik cenderung menggunakan pendekatan alamiah. Ia melukiskan negara atau asosiasi politik lahir melalui proses alam dan perkembangan yang diperlukan dalam hidup manusia. Hakikat moral manusia dalam sifat-sifatnyayang khusus dapat terbentuk dan mencapai bentuknya yang tinggi bila manusia berada dalam sebuah negara. Ia mengemukakan: "Manusia adalah hewan yang didorong oleh lingkungan (alamnya) untuk kehidupan yang berbudi luhur."

Selanjutnya, Plato memberikan teori politiknya dengan menunjukkan bahwa keadilan yang sebenarnya hanya dapat terwujud dalam konteks negara Republik. Negara inilah yang memadukan filsafat dan kekuatan politik. Sementara itu, logika Aristoteles seolah-olah menyatakan bahwa pemenuhan berbagai kebutuhan biologis, sosial, dan etika manusia hanya dapat diperoleh jika ia tergabung ke dalam aneka asosiasi yang bermula dari keluarga dan berakhir pada negara. Sebab, segala sesuatu ditentukan oleh tujuan akhirnya, teleologi. Aristoteles menganggap keanggotaan dalam sebuah masyarakat sipil sebagai prasyarat bagi aktualisasi kemampuan manusia seutuhnya. Oleh karena itu manusia yang berada diluar asosiasi politik akan gagal menunjukkan sifat-sifat dan potensi-potensi manusianya, atau bahakan akan berprilaku melebihi binatang buas atau dewa (Tuhan).

Dalam literatur Arab dan Islam telah lama dikenal satu Istilah yang secara substansi tidak jauh berbeda dengan istilah politik, yaitu "Siasah" bahkan pengertiannya terasa lebih menyeluruh dibanding dengan pengertian politik. Dalam literatur klasik istilah siasah telah dikenal secara luas dan mengacu kepada urusan yang memerlukan penegendalian, pengkhidmatan, dan kepemimpinan.

Kata "siasah" berasal dari kata kerja "sasa" yang mempunyai dua pola, yakni sasa-yasusu-sausan dan pola yang kedua adalah sasa-yasusu-siyasatan. 
Dalam bahasa Arab akar kata ini bermakna ganda yaitu kerusakan sesuatu dan tabiat atau sifat dasar. Dari makna pertama diperoleh makna leksikal menjadi rusak atau banyak kutu, sedangkan dari makna kedua diperoleh makna memegang kepemimpinan atas masyarakat, menuntun atau melatih hewan, mengatur atau memelihara urusan. Dalam hadis Rasululloh saw, kata "siasah" dipergunakan setidak-tidaknya dua kali. Pertama, ketika beliau menyebut kepemimpinan atas Bani Israil oleh para nabi. Kedua, ketika beliau menuntun kudanya dari halaman masjid Nabawi. Memang pengertian siasah telah banyak dikemukakan para ahli. Antara lain dirumuskan bahwa siasah adalah seni memerintah dan mengelola negara. Ahli lain menyatakan bahwa siasah adalah kekuatan (power) dan kemampuan merealisasikan tujuan yang ingin dicapai. Yang lainnya merumuskan siasah sebagai seni tawar menawar (bargaining).

Berbeda dengan penekanan-penekanan tersebut diatas, Imam Ibnu Qayyim Al Jauziyah lebih menekankan arti siasah dengan upaya perbaikan kehidupan manusia dan penghindaraan kerusakan. Sedangkan keadilan dipandang sebagai landasan alamiah utama yang dapat melahirkan perbaikan bagi hidup manusia. Oleh karena itu ia melukiskan siasah sebagai upaya mengantarkan manusia ke kehidupan yang lebih dekat dengan perbaikan dan jauh dari kerusakan. Selanjutnya ia mengaskan, jalan apapun yang dapat mewujudkan keadilan adalah bagian dari din, meskipun tidak ditegaskan oleh seorang rasul atau tidak dieksplisitkan oleh wahyu.

Dalam kajian ilmu komunikasi, penelitian yang menunjukan adanya pengaruh besar dari suatu pesan yang dikomunikasikan terhadap komunikan (pendengar atau pembaca) dapat ditelusuri melalui teori model Jarum Hipodermik. Model ini mempunyai asumsi bahwa komponen-komponen komunikasi (komunikator, pesan, media) amat perkasa dalam mempengaruhi komunikan. Disebut model jarum hipodermik karena dalam model ini dikesankan seakan-akan komunikasi "disuntikan" langsung kedalam jiwa komunikan. Bila kita menggunakan komunikator yang tepat, pesan yang baik, atau media yang benar, komunikan dapat diarahkan sekehendak kita.

Variabel-variabel pesan yang didalamnya terdiri dari struktur pesan, gaya pesan, appeals (tingkat kemenarikan) pesan serta sistematika penulisan dan penyampaian pesan mempunyai pengaruh besar terhadap segi kognitif (perubahan pendapat, penambahan pengetahuan dan perubahan kepercayaan), segi afektif (sikap, perasaan, kesukaan), dan segi behavioral (perilaku atau kecenderungan perilaku). Pesan yang ditranmisikan melalui media massa, sebelumnya akan melewati variabel antara yang berupa perhatian, pengertian dan penerimaan, serta selanjutnya mempengaruhi pembaca.

Hubungan dengan dakwah melalui siasah, bahwa kegitan dakwah ini harus mampu menginduksikan nilai-nilai risalah Islam dalam kegiatan politik. Tidak hanya kekuasaan semata yang menjadi orientasi utama, lebh dari itu adalah

Anida: Aktualisasi Nuansa Ilmu Dakwah 17(2) (2017) 19-36 
terbumikannya Islam sebagai sebuah landasan gerak kader dan partai politik dalam rangka membina umat. Pesan atau informasi dakwah baik lisan maupun tulisan harus semenarik mungkin dan berangkat dari metodologi dakwah yang benar, sehingga dapat membuat mad'u berprilaku seperti yang diharapkan oleh da'i.

Wilbur Schram memberikan acuan agar pesan menumbuhkan respon positif, antara lain: Pesan agar mengungkapkan lambang-lambang yang mengingatkan penerima kepada pengalaman yang dikaitkan dengan paham yang sama di pihak sumber, sehingga terdapat kesamaan pengertian. Pesan agar disusun sedemekian rupa sehingga menumbuhkan minat pada pihak penerima pesan atau komunikan. Pesan agar dapat menyarankan berbagai cara pemecahan masalah serasi dengan situasi kelompok, dalam mana komunikan berada untuk menentukan responnya.

Pesan agar dapat menumbuhkan kebutuhan pribadi pada pihak komunikan serta menyarankan beberapa cara untuk memenuhi kebutuhan yang timbul pada pihak komunikan. Penyampaian pesan harus benar-benar sistematis karena pesan bisa diharapkan mewakili apa-apa yang disampaikan da'i sehingga mad'u bisa mengikuti keinginan da'i. Komunikasi harus memberikan stimulus (perangsang bagi diri komunikan), perihal pesan tersebut, sehingga sikap, ide, pemahaman tersebut dapat dimengerti komunikan.

Siahaan memberikan acuan dalam penyusunan pesan, antara lain: Cukup jelas, yaitu tidak menyampikan pesan tersebut dengan kalimat yang berbelit-belit. Lebih jelasnya, menggunakan bahasa yang mudah dimengerti. Mengundang kebenaran, yaitu berdasaarkan fakta dan menghindari kesalahan-kesalahan. Ringkas, artinya tulisan harus menggunakan kalimat-kalimat pendek yang lengkap dan berarti. Mencakup keseluruhan akan apa yang ingin disampaikan. Lengkap, artinya tidak ada yang terlupa atau tersirat, maupun yang harus lebih dahulu ditafsirkan, kalau memang si penerima diharapkan ingin menangkap pesan yang disampaikan.

Nyata, maksudnya pesan harus bisa dipertanggung jawabkan dengan adanya dasar dan faktanya. Menarik dan meyakinkan, maksudnya pesan yang akan disampaikan harus menarik orang yang akan membacanya. Sopan, karena komunikan itu mempunyai harga diri, maka penyampaian pesan harus sopan, baik dalam cara penyampaian maupun kata-kata pesan yang akan disampaikan. Kaitannya cukup erat, hal ini dimaksudkan supaya isi pesan tidak mengandung pertentangan antara bagian pasan yang satu dengan bagian pesan yang lain.

Sementara itu, sudah hampir menjadi suatu rumusan kehidupan, bahwa siapapun, baik individu maupun masyarakat akan selalu menginginkan keadaan yang selalu lebih baik dan lebih maju dibandingkan sebelumnya. Tujuan dakwah sendiri tidak lain adalah membawa masyarakat pada keadaan yang lebih baik dan lebih maju dibandingkan dengan keadaan sebelumnya. Menurut para ahli 
sosiologi, teori tentang kemajuaan selalu menyangkit dua fokus perkembangan: pertama, perkembangan dalam struktur atas atau kesadaran manusia tentang diri sendiri dan alam sekelilingnya; kedua, perkembangan struktur bawah atau kondisi sosial/ material dalam kehidupan manusia. Pemikir pertama pada zaman modern yang berbicara mengenai kesadaran atau cara berpikir manusia adalah Auguste Comte.

Para pemikir lain pada dasarnya mengikuti pendapatnya. Sedangkan yang mengemukakan pendapatnya mengenai perkembangan mengenai kondisi sosial antara lain adalah Spencer, Saint Simont, dan Karl Marx. Para pemikir evolusi sosial tersebut sebagian besar sebenarnya mengikuti teori Darwin, yang mengemukakan suatu teori evolusi dalam biologi. Mereka ini menerapkan teori Darwin di bidang sosial. tetapi perlu dicatat disini bahwa Comte mengemukakan teori evolusi pemikirannya sebelum Darwin.

Menurut Hisham Al-Thalib, seorang Muslim bukanlah orang yang bertempur melawan setan melalui pedang, lalu masuk surga. Dia harus berinteraksi dengan lingkungannnya dan melakukan perubahan demi perbuhan (dakwah). Bagi kalangan ahli sosiologi seperti Haferkamp dan Smelser, perubahan merupakan gambaran nyata dari realitas sosial yang semua teori awal sosial dengan titik awal konseptual yang berbeda-beda segera akan membahasnya. Dan para teoritisi ilmu sosial sepakat bahwa manusia adalah para pelaku yang menciptakan perubahan-perubahan dalam sejarah. Gerak sejarah adalah gerak menuju suatu tujuan. Tujuan tersebut ada dihadapan manusia, berada dimasa depan. Sedangkan masa depan yang bertujuan harus tergambar dalam benak manusia. Dengan demikian langkah manusia merupakan langkah pertama dari gerak sejarah, atau dengan kata lain dari terjadinya perubahan.

Lebih jauh lagi pada tataran ini akan berlaku hukum dialektika kausalitas, dalam pengertian semakin berkualitas pesan yang disampaikan oleh para ulama salaf, maka akan semakin besar pengaruh terhadap mad'u nya. Sebaliknya, semakin tidak berkualitas pesan yang disampaikan, maka akan semakin ditinggalkan oleh mad'u nya, dan kalaupun diperhatikan, maka akan sedikit sekali pengaruh terhadap mad'u tersebut. Oleh karena itu serangkaian penelitian yang mendalam terhadap isi pesan dalam suatu aktivitas dakwah menjadi hal yang sangat penting.

\section{DAFTAR PUSTAKA}

Ahmad, A. (1983).Dakwah dan Perubahan Sosial. Yogyakarta: PLP2M. 
al-Khuli, A. (1982).Tazkirah al-Du'ah. Mesir: Dar al-Kitab al-Arabi. an-Nabhani, T.(2005). Konsepsi Politik Hizbut Tabrir. Hizbut Tahrir.

Anshari, E.S. (1982).W awasan Islam: Pokok-Pokok Pikiran Tentang Islam. Bandung: Pustaka Salman.

Atjeh, A.(2004) Potret Dakwah Mubammad SAW dan Para Sahabatnya. Solo: Ramadhani.

Bulaeng, A. (2004). Metode Penelitian Komunikasi Kontemporer .Yogyakarta: Andi Offset.

Depag RI. (2005). Al-Quran dan terjemahnya. Bandung: J-ART.

Diknas. (2001). Kamus Besar Bahasa Indonesia. Jakarta: Balai Pustaka.

Fatwa, A.M. (2002). Satu Islam Multipartai; Membangun integritas di tengah pluralitas. Bandung: Mizan.

Hafidhuddin, D. (1998). Dakwah Aktual. Jakarta: Gema Insani Press.

Hamka. (1982).Prinsip-Prinsip dan Kebijaksanaan Dakwah Islam. Jakarta: Umminda.

Kazhim, M. \& Hamzah,A. (1999). 5 Partai dalam Timbangan; Analisis dan Prosfek.

Bandung: Pustaka Hidayah,.

Kusnawan, A. (2004).Berdakwah Lewat Tulisan. Bandung: Mujahid.

Kusnawan, A. \&Muhyidin, A. (2004). Ilmu Dakwah; Dakwah dalam Al-Qur'an.

Bandung: Pustaka Bani Quraisy.

Muhadjir, N. (1996).Metodologi Penelitian Kualitatif. Yogyakarta: Rake Sarasin.

Mulkhan, A.M. (1996). Ideologisasi Gerakan Dakwah. Yogyakarta: Sipress.

Munawir, A.W. (1984). Kamus Besar Arab-Indonesia. Yogyakarta: Ponpes alMunawwir.

Pratiknya, A.W. (1983) Islam dan Dakwah: Pergumulan Antara Nilai dan Realitas Yogyakarta: Majlis Tabligh PP. Muhammadiyah.

Subandi, A. (1994). Ilmu Dakwah: Pengantar ke Arah Metodologi. Bandung: Yayasan Syahida.

Surakhmand,G.W. (1999).Penelitian Ilmiah: Dasar, Metode dan Teknik. Bandung: Tarsito.

Syukir, A. (1983). Dasar-Dasar Strategi Dakwah Islam. Surabaya: al-Ikhlas.

Rakhmat, J. (2005). Rekayasa Sosial: Revolusi, Reformasi atau Manusia Besar?. Bandung: Remaja Rosdakarya.

Ridha, A. (1986). Amal Siyasi; Gerakan politik dalam dakwah. Bandung: Syaamil.

Siahaan, (1991).Komunikasi: Pemahaman dan Penerapannya. Jakarta: BPK Gunung Mulia.

Zaidan,A.K. (1980).Dasar-Dasar Dakwah. Jakarta: Paramadina. 